\title{
Children's (in)visibility in social vulnerability and the impact of the novel coronavirus (COVID-19)
}

\author{
A (in)visibilidade da criança em vulnerabilidade social e o impacto do novo coronavírus (COVID19) \\ La (in)visibilidad del niño en la vulnerabilidad social y el impacto del nuevo coronavirus (COVID19)
}

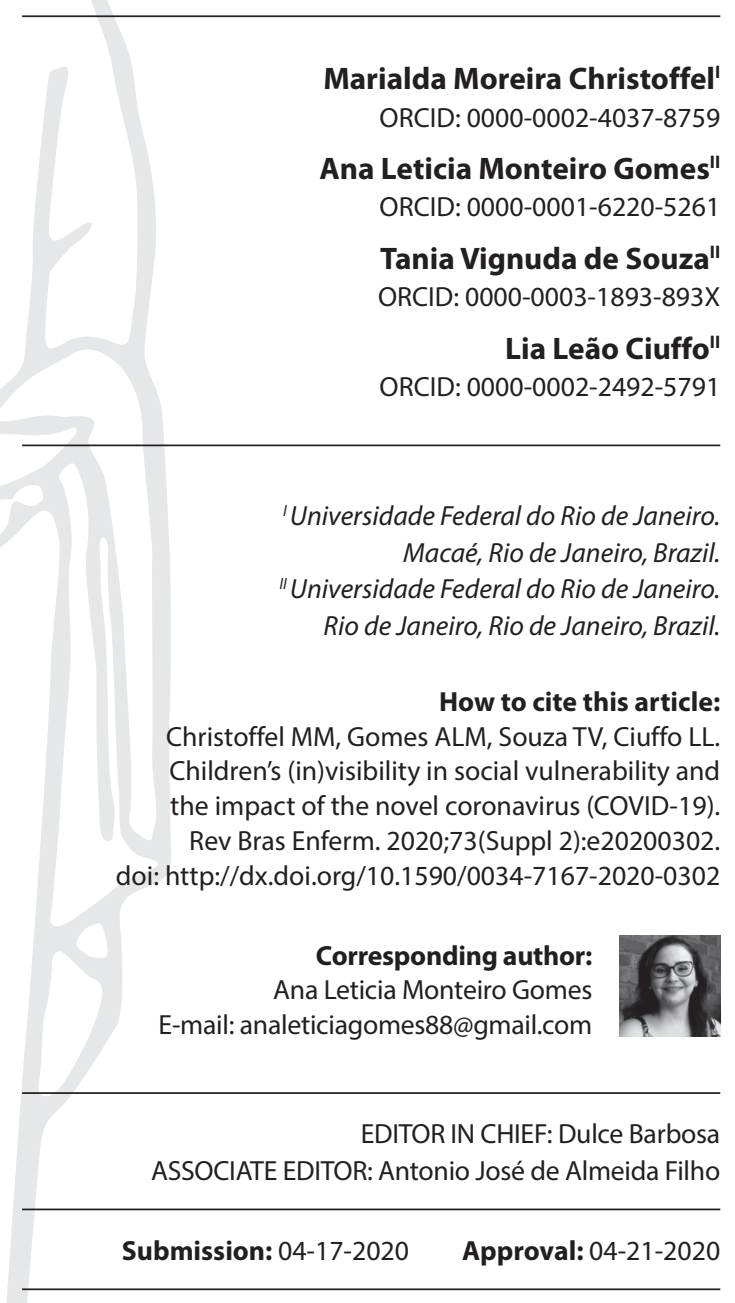

\begin{abstract}
Objective: To examine the impact of the infection by the novel coronavirus on Brazilian children in situation of social vulnerability based on the Millennium Sustainable Development Goals. Method: Reflective study based on discursive formulation in three aspects: principles of the objectives and goals for the millennium sustainable development; impact of the pandemic on the health of children and their families living in social vulnerability; and the role of pediatric nursing in the care provided - limits and challenges. Results: In January 2020, the news of COVID 19 is released as a pandemic. In Brazil, children and families are still without access to basic rights, thereby increasing their risks of social vulnerability because of the quarantine. The nursing field has an important role in monitoring children and their families, offering guidance in search for solutions and preventing contamination. Conclusion: There are still challenges to be overcome by the children and their families in situations of vulnerability against COVID-19. Descriptors: Coronavirus Infections; Children; Vulnerable Population; Sustainable Development; Pediatric Nursing.
\end{abstract}

\section{RESUMO}

Objetivo: Refletir sobre o impacto da infecção pelo novo coronavírus nas crianças brasileiras em situação de vulnerabilidade social, com base nos Objetivos de Desenvolvimento Sustentável do Milênio. Método: Estudo reflexivo fundamentado na formulação discursiva em três momentos: princípios dos objetivos e das metas de desenvolvimento sustentável do milênio; impacto da pandemia na saúde das crianças e famílias em vulnerabilidade social; e o papel da enfermagem pediátrica nos cuidados prestados - limites e desafios. Resultados: Em janeiro de 2020, a COVID19 é divulgada como pandemia. No Brasil, crianças e famílias ainda se encontram sem acesso a direitos básicos, aumentando os riscos de vulnerabilidade social pela quarentena. A enfermagem tem papel relevante no acompanhamento das crianças e suas famílias, oferecendo orientações na busca de soluções e na prevenção da contaminação. Conclusão: Ainda existem desafios a serem superados pelas crianças e suas famílias em situação de vulnerabilidade diante da COVID-19.

Descritores: Infecções por Coronavírus; Criança; Vulnerabilidade Social; Desenvolvimento Sustentável; Enfermagem Pediátrica.

\section{RESUMEN}

Objetivo: Reflexionar sobre el impacto de la infección por el nuevo coronavirus en los niños brasileños en situación de vulnerabilidad social, con base en los Objetivos de Desarrollo Sustentable del Milenio. Método: Estudio reflexivo fundamentado en la formulación discursiva en tres momentos: principios de los objetivos y de las metas de desarrollo sustentable del milenio; impacto de la pandemia en la salud de los niños y familias en vulnerabilidad social; y el papel de la enfermería pediátrica en los cuidados prestados - límites y desafíos. Resultados: En enero de 2020, el COVID-19 ha sido divulgado como pandemia. En Brasil, niños y familias aún se encuentran sin acceso a derechos básicos, aumentando los riesgos de vulnerabilidad social por la cuarentena. La enfermería tiene papel relevante en el acompañamiento de los niños y sus familias, ofreciendo orientaciones en la búsqueda de soluciones y en la prevención de la contaminación. Conclusión: Aún hay desafíos a ser superados por los niños y sus familias en situación de vulnerabilidad delante del COVID-19. Descriptores: Infecciones por Coronavirus; Niños; Vulnerabilidad Social; Desarrollo Sustentable; Enfermería Pediátrica. 


\section{INTRODUCTION}

In early December 2019, several cases of pneumonia of unknown origin emerged in Wuhan, Hubei province, China. Most patients diagnosed with this pneumonia reported exposure to the Wholesale Seafood Market, which sells many species of live animals ${ }^{(1)}$.

On January 3,2020, a new member of the coronavirus family was identified in samples of bronchoalveolar lavage fluid from a patient in Wuhan. The novel virus has been confirmed by the Chinese Center for Disease Control and Prevention as the cause of the disease under investigation and has spread rapidly across China and other continents ${ }^{(1)}$.

On January 7, 2020, the World Health Organization (WHO) named the newly discovered etiologic agent as the novel coronavirus, which causes Severe Acute Respiratory Syndrome, also known as SARS-CoV-2 or COVID-19 (so named on February 11, 2020)(1).

On January 11, WHO declared the issue as a public health emergency of international concern, since the virus was spreading worldwide, and it was characterized as a pandemic. By that time several countries had already confirmed cases of COVID-19, including the United States of America, Germany and Japan (1).

COVID-19 affects all age groups, varying from mild symptoms to severe respiratory conditions, especially severe pneumonia. Symptoms include fever, cough, nasal congestion, runny nose, sore throat, but there may also be an increase in respiratory rate, wheezing and pneumonia up to severe acute respiratory syndrome, or, in some cases, respiratory failure. Gastrointestinal symptoms such as vomiting and diarrhea can also happen, but are more common in children than in adults ${ }^{(1-2)}$.

As far as the children's age is concerned, the data show that, so far, infection with SARS-CoV-2 rarely affects children; and when children manifest symptoms of the disease, they are most often mild. Thus, in most cases, children are asymptomatic carriers of the virus. However, their potential to transmit the virus has not been ruled out even if they do not show clinical manifestations ${ }^{(1-2)}$.

A type of medical research conducted in China, known as clinical series, tracked 2,143 pediatric patients with COVID-19 reported to the Chinese Center for Disease Control and Prevention, from January 16 to February 8, 2020. The results revealed 731 (34.1\%) laboratory confirmed cases and 1,412 (65.9\%) suspected cases. The average age of all cases in children was 7 years (interquartile range: $2-13$ ), and 1,213 cases (56.6\%) were boys. Over $90 \%$ of all cases in children were asymptomatic, mild, or moderate. The median time from disease onset to diagnosis was 2 days (interval: 0 to 42 days). They reached a conclusion that, although the clinical manifestations of COVID-19 cases in children were generally less severe than in adult patients, young children, especially babies, were vulnerable to the infection ${ }^{(1)}$.

Recent results from another Chinese study show that of the total reported cases of the disease, only $0.9 \%$ occurred in children, totaling 416 cases in the range of 0 to 9 years, none of which evolved to death; in relation to adolescents from 10 to 19 years of age, 549 cases (1.2\%) were totaled, with 1 death $(0.1 \%)$ of a 13 -year-old adolescent. The lethality rate is $0.2 \%$ in patients between 10 and 19 years of age ${ }^{(3)}$.

Based on limited, however, current evidence, on March 30, 2020, the American Academy of Pediatrics and the Brazilian Society of Pediatrics, and following suit, on April 6, 2020, the Brazilian Association of Midwives and Obstetric Nurses and the Brazilian Society of Pediatric Nurses, provided temporary guidance for clinical management of newborns of mothers with suspected or confirmed diagnosis of COVID-19, as well as clinical management of children with the virus. It was also informed that, until then, vertical transmission had not been proven ${ }^{(2)}$.

In Brazil, until 04:00 PM on April 6, 2020, 12,056 cases were confirmed, 553 deaths and a lethality rate of $4.6 \%$, but there was no age stratification from those infected. It is known that $58 \%(n=7,046)$ of confirmed cases are located in the Southeast region. The state of Rio de Janeiro holds 1,461 of the total cases, 8 of them are children 0 to 10 years old. The data reveal 71 deaths, showing a lethality rate of $4.9 \%$, but with no deaths registered in the age group from 0 to 10 years old until then ${ }^{(4)}$.

In facing this pandemic, it is necessary to reflect on the sustainable development of the millennium in times of COVID-19, as many are the challenges to combat the pandemic in children and families in situations of social vulnerability.

\section{OBJECTIVE}

Reflect on the impact of the infection by the novel coronavirus on Brazilian children in situations of social vulnerability considering the Millennium Sustainable Development Goals.

\section{METHODS}

It is a reflective study based on discursive formulation in three aspects: the principles of the objectives and goals of sustainable development of the millennium; the impact of the pandemic on the health of children and families in social vulnerability; and the role of pediatric nursing in the care provided - limits and challenges.

\section{The principles of the Millennium Sustainable Develop- ment Goals and the challenges before and after COVID-19}

The Agenda 2030 Sustainable Development Goals (SDGs) comprise 17 objectives and 169 goals and can be defined as a model to provide the integration between economy, society and the environment, that is, it is the notion that economic growth must take into account not only social inclusion, but also environmental protection ${ }^{(5)}$.

These goals involve fields or topics relevant to improving child health, such as poverty eradication, food security and agriculture, good health, education, gender equality, reducing inequality, energy, clean water and sanitation, sustainable patterns of production and consumption, climate action, sustainable cities, protection and sustainable usage of resources from oceans and terrestrial ecosystems, comprehensive economic growth, infrastructure and industrialization, organization and means for implementing those policies ${ }^{(5)}$.

In this sense, the area of maternal, neonatal and child health stands out as a great challenge, since many women and children live in vulnerable conditions and must be made aware of their rights. To this end, it is necessary to undertake efforts to strengthen public policies to assist these groups. 
Whereas the needs experienced by certain populations and people in social vulnerability place them in a situation where greater social and health needs arise, the lack of access to quality health services, treatments and technologies has a negative effect on the health and life/death of these social groups ${ }^{(6)}$, especially with regard to the children's public, since children exposed to adverse health conditions, if they survive, may present problems in their growth and development.

According to UNICEF (2020), some millennium sustainable development goals are directly connected to the topics without girls and boys cannot survive, thrive and develop their full potential: food, health care, clean water, education and fight against poverty ${ }^{(5)}$.

From the health perspective, the social determinants, the need to strengthen health systems and the social safety net affect the health of children and families in vulnerable situations, such as people living in informal settlements, homeless people, populations in rural areas, children, people with disabilities, immigrants, refugees, people at risk from disaster and all other vulnerable groups.

In 2000, Brazil was considered a country of high social vulnerability, but had this index reduced, in 2010, to the middle social vulnerability range. The social vulnerability index (SoVI) is calculated based on three dimensions: income and work; human capital; and urban infrastructure ${ }^{(7)}$.

It is known that Brazilian macro-regional inequalities are still maintained, in which the North and Northeast present predominantly higher SoVI, while the cities of the Center-South of the country present better results, with a decrease of this index ${ }^{(7)}$.

Regarding the Brazilian human infrastructure dimension, there are still populations living in urban households without garbage collection service and with inadequate water supply and sanitation ${ }^{(7)}$.

In relation to human capital, we still have children who do not attend school, while many others spend years in the classroom and do not learn even the basic skills. The goal on education addresses access to learning opportunities and the quality of teaching.

The SDGs on poverty, inequality and gender discrimination highlight that children and their families are not receiving fair opportunities, therefore there is a need for actions to strengthen social protection systems ${ }^{(5)}$.

Consequently, the objectives and SDGs to be achieved are complex and require an investment in time to create public policies that will address so many issues concerning citizen's rights, especially children's rights.

It is noted that issues related to the situation of social vulnerability still present today in Brazil and in other countries, were already in place before the COVID-19 pandemic. Therefore, it is necessary to reflect on the impact of this infection on the achievement of the objectives and SDGs proposed for the year 2030, with a view to reducing this vulnerability.

\section{Impact of the pandemic on the health of children and families in social vulnerability}

Social vulnerability can be perceived as the resilience of communities when confronted by external health stressors such as natural or human-made disasters or disease epidemics. Reducing social vulnerability can reduce both human suffering and economic losses ${ }^{(8)}$.

Based on the above-mentioned concept, the elements considered of vulnerability in the child's development and social inequities according to the nurse's point of view who is integrated in the Family Health Strategy are: low parental education; unemployment; low income; lack of basic sanitation; precarious housing situation; no access to professionalization, social programs and vacancies in daycare centers. It is important to note that vulnerability in children's development is also related to socioeconomic elements and that their understanding extends beyond the biological and individual components of children's development $^{(9)}$.

In developing countries, one of the most important aspects that must be highlighted is the contradictions between what is a citizen's right and the scope of the less favored population to these rights, especially regarding basic issues such as housing, health, school, among others.

So, at this time of the pandemic of the novel coronavirus, according to the recommendation of the Ministry of Health, in compliance with the National Contingency Plan for Human Infection by the novel Coronavirus, there must be a social isolation, whose main measures are: strict hand hygiene and respiratory etiquette, as well as to avoid crowding, to adopt social distancing measures, such as maintaining a 4.92 feet distance apart from another person when outdoors, but mainly to stay indoors, except for those who work in essential activities, such as supermarkets, pharmacies, health units and others.

However, in order to meet these measures, it is necessary to reflect on which part of the Brazilian population lives in communities that do not have adequate infrastructure and basic sanitation, thus presenting difficulties in relation to personal hygiene and the environment. Many families live in narrow rooms, in conditions that do not favor isolation in case someone becomes contaminated with the coronavirus. The main source of family income is often obtained from informal and face-to-face activities, making it impossible to do their work remotely, among many other problems.

Therefore, the pandemic of the novel coronavirus (COVID-19) may change the reality experienced by children for worse, in view of schools closing the doors and commute restrictions, which will disrupt children's routine and social support, adding new stress on parents and custodians, who must find new options to care for the children at home, such as offering activities and food that are usually provided at school ${ }^{(10)}$.

The marginalization and discrimination related to COVID-19 can make children more exposed to violence and psychological distress, that is, children and families who are already vulnerable due to socio-economic exclusion or those who living in overcrowded places are particularly at risk ${ }^{(10)}$.

\section{Role of the pediatric nurse providing health care - limits and challenges in times of pandemic of the novel coronavirus}

It is clear that nursing practice should be aligned with other professionals and sectors of the health area, in order to seek the convergence of actions aimed at patients, in a joint effort that allows 
the exchange of knowledge and enhances the offer of more effective and resolutive care with a view to full attention to the patient.

Nursing practices should also be attuned to the demands and needs of their territories. Among these demands are both those related to the care of children and their families in situations of social vulnerability during the pandemic, and those related to the fight for a State that fulfills the social rights guaranteed by the Federal Constitution ${ }^{(6)}$.

In this line, it is essential that nursing works its technical and scientific knowledge with the children's families in order to promote actions that transform reality in order to empower them, so that together they fight for the fulfilment of the basic rights of the entire population.

Among the transformative actions mentioned above, we highlight those related to the education of children and families about the pandemic prevention measures, such as frequent hand washing with soap and water, the correct and rational use of supplies such as hand sanitizer with $70 \%$ gel alcohol and masks for personal protection. In addition, the nursing staff should also advise on cleaning and disinfecting household environments using cloths moistened with disinfectant products in the correct concentration - for example, sodium hypochlorite.

Such personal hygiene and environmental measures are the basis of Florence Nightingale's environmentalist theory, which, to this day, is one of the main foundations of our profession. It is necessary to explain that to the general population and especially to the children, since they are often the ones who learn and spread the knowledge wherever they go.

The nursing staff and the pediatric nurse also play an important role in assisting during a possible hospitalization of the child. However, in order for assistance to occur in the manner recommended, it is necessary to discuss issues related to the lack of provision of individual protection resources and technologies, which at the moment are configured as one of the main limits for nursing to provide risk-free assistance to itself.

The challenges for the practice of nursing go beyond the acquisition of resources and technology, and it is necessary to invest in this professional in order to have knowledge about the rule of law. So, in order to fight for the reduction of social inequalities, it is necessary to create intersectoral instances, beyond the scope of the health field, that converge their resources in the formulation of public policies that provide the guarantee of the full enjoyment of social rights by all people of our society and of the planetary community ${ }^{(6)}$.

\section{Study limitations}

The central idea of the study is not to exhaust concepts, theories, methods and possibilities concerning the impact of the infection by the novel coronavirus in Brazilian children, but to provoke reflections to achieve the Millennium Sustainable Development Goals and also to point out guidelines that may sustain the debates between educational and health institutions.

\section{Contributions to the field}

This reflection article can contribute both to the formation processes and to health institutions, since it brings updated evidence. In this perspective, it is thought that the considerations now exposed are valuable to the nursing action before the child and the family in a situation of social vulnerability. This being said, the contribution of this study is found in the possibilities of health actions that encompass the inclusion of vulnerable populations in the Brazilian context, aiming at the improvement of care and services in health.

\section{CONCLUSION}

It is concluded that, in line with the sustainable millennium goals, there are still challenges to be overcome for children and their families in vulnerable situations in the fight against the COVID-19, such as access to water for personal and environmental hygiene and responding to the decrease in family income through quarantine. In this sense, pediatric nursing has an important role in promoting prevention measures, as well as in detecting and evaluating suspected cases of COVID-19. In addition, nursing professionals should advocate for ensuring the full enjoyment of social rights, especially for the children and their families.

\section{REFERENCES}

1. Dong Y, Mo X, Hu Y, Qi X, Jiang F, Jiang Z, et al. Epidemiological characteristics of 2143 pediatric patients with 2019 coronavirus disease in China. Pediatrics. 2020;16(0):e20200702. doi: 10.1542/peds.2020-0702

2. Sociedade Brasileira de Pediatria (BR). Departamento científico de infectologia. Orientações a Respeito da Infecção pelo SARS-CoV-2 (conhecida como COVID-19) em Crianças. [Internet]. 2020 [cited 2020 Apr 10]. Available from: https://www.sbp.com.br/fileadmin/user_ upload/Covid-19-Pais-DC-Infecto-DS_Rosely_Alves_Sobral_-convertido.pdf

3. The Novel Coronavirus Pneumonia Emergency Response Epidemiology Team. CDC-China (CH). The Epidemiological Characteristics of an Outbreak of 2019 Novel Coronavirus Diseases (COVID-19) — China. [Internet]. 2020. [cited 2020 Apr 10]; 2(0):1-10. Available from: https:// github.com/cmrivers/ncov/blob/master/COVID-19.pdf

4. Ministério da Saúde (BR). Painel Coronavírus[Internet]. 2020. [cited 2020 Apr 10]; Available from: https://covid.saude.gov.br/

5. Unicef. Objetivos de Desenvolvimento Sustentável: ainda é possível mudar 2030[Internet]. 2020[cited 2020 Apr 10]. Available from: https:// www.unicef.org/brazil/objetivos-de-desenvolvimento-sustentavel

6. Fiorati RC, Arcênico, RA, Souza LB. Social inequalities and access to health: challenges for society and the nursing field. Rev Latino-Am Enfermagem. 2016;24:e2683. doi: 10.1590/1518-8345.0945.2687 
7. Ipea (BR). Atlas da vulnerabilidade social nos municípios brasileiros. [Internet] Brasília: IPEA; 2015. [cited 2020 Apr 10]; Available from: http:// ivs.ipea.gov.br/images/publicacoes/Ivs/publicacao_atlas_ivs.pdf. ISBN: 978-85-7811-255-4

8. Biblioteca Virtual em Saúde (BR). Descritores em Ciência da Saúde [Internet]. 2020[cited 2020 Apr 10]. Available from: http://decs.bvs.br/ cgi-bin/wxis1660.exe/decsserver/

9. Silva DI, Larocca LM, Chaves MMN, Mazza VA. [Vulnerability in child development: influence of social inequities]. Rev Bras Promoç Saúde [Internet]. 2015[cited 2020 Apr 10];28(1):58-66. Available from: https://periodicos.unifor.br/RBPS/article/view/3141

10. Aliança para a Proteção da Criança em Ações Humanitárias. Nota Técnica: Proteção da Criança durante a Pandemia do Coronavírus[Internet]. 2020[cited 2020 Apr 10]. Available from: https://www.unicef.org/brazil/media/7561/file 